\title{
The assessment of haemodynamic stability, gas exchange parameters, and the quality of postoperative analgesia in patients undergoing arthroscopic shoulder joint surgery in two different types of anaesthesia - preliminary research
}

\section{Ocena stabilności hemodynamicznej, parametrów wymiany gazowej oraz jakości analgezji pooperacyjnej u chorych poddawanych artroskopii stawu barkowego w dwóch różnych typach znieczulenia - badanie wstępne}

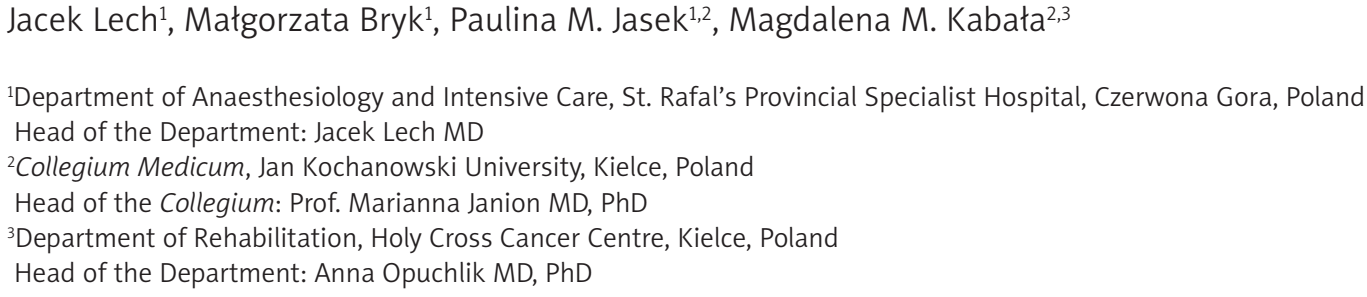

Key words: anaesthesia, controlled hypotension, arthroscopic shoulder joint surgery.

Słowa kluczowe: znieczulenie, hipotensja kontrolowana, artroskopia stawu barkowego.

\begin{abstract}
Introduction: There are several methods available to conduct anaesthesia in patients undergoing arthroscopic shoulder joint surgery. The main aim of anaesthesia is to reach controlled hypotension to reduce bleeding in the operating field.

Aim of the research: To assess haemodynamic stability in patients undergoing arthroscopic shoulder joint surgery in two different types of anaesthesia: complex general anaesthesia and complex general and regional anaesthesia.

Material and methods: The research included 20 patients who underwent arthroscopic shoulder joint surgery in St. Rafal's Provincial Specialist Hospital in Czerwona Gora. Patients were randomly assigned into two groups - A and B. Patients from group A were subjected to complex general anaesthesia by infusion of remifentanil. In group B patients, brachial plexus block was performed. During anaesthesia haemodynamic parameters were monitored, and gas exchange parameters, the level of lactates, and the effectiveness of post-operative analgesia were assessed.

Results: Heart rate (HR) parameters between the two groups differed substantially after $30 \mathrm{~min}$. $U$ Mann-Whitney Test indicated salience $p=0.009$. In group A HR and mean arterial pressure parameters were similar, which proves better haemodynamic stability. In group A the arterial blood $\mathrm{pH}$ value showed similar values $(p=0.001)$, which indicates better stability of the acid-base balance. Post-operative pain in group A was more persistent than in group B and required a supply of morphine in a higher dose.

Conclusions: The application of remifentanil results in higher haemodynamic stability in comparison to anaesthesia with brachial plexus block; however, the usage of block results in better post-operative analgesia in comparison to the first method.
\end{abstract}

\section{Streszczenie}

Wprowadzenie: Istnieje kilka metod przeprowadzenia znieczulenia u pacjentów poddawanych zabiegowi artroskopii stawu barkowego. Istotą znieczulenia jest uzyskanie hipotensji kontrolowanej w celu zmniejszenia krwawienia w polu operacyjnym.

Cel pracy: Ocena stabilności hemodynamicznej u pacjentów poddawanych artroskopii stawu barkowego w dwóch różnych typach znieczulenia: ogólnym złożonym oraz ogólnym złożonym i regionalnym.

Materiał i metody: W badaniu wzięło udział 20 pacjentów poddanych artroskopii stawu barkowego w Wojewódzkim Szpitalu Specjalistycznym im. św. Rafała w Czerwonej Górze. Chorych losowo podzielono na dwie grupy - A i B. Pacjentów z grupy A poddawano znieczuleniu ogólnemu złożonemu z użyciem remifentanylu. U pacjentów z grupy B wykonywano dodatkowo blokadę splotu barkowego. $\mathrm{W}$ trakcie trwania znieczulenia rejestrowano parametry hemodynamiczne, oceniano parametry wymiany gazowej, stężenie mleczanów oraz skuteczność analgezji pooperacyjnej. 
Wyniki: Parametry tętna (HR) pomiędzy grupa A i B różniły się znacznie po 30 minutach. W teście $U$ Manna-Whitneya stwierdzono istotność $p=0,009$. W grupie A wartości HR oraz średnie ciśnienie tętnicze (MAP) były zbliżone, co świadczy o lepszej stabilności hemodynamicznej. W grupie A wykazywano zbliżone wartości $(p=0,001) \mathrm{pH}$ krwi tętniczej, co przemawia za lepszą stabilizacją równowagi kwasowo-zasadowej. Ból pooperacyjny w grupie A był bardziej nasilony niż w grupie B i wymagał podania większych dawek morfiny.

Wnioski: Zastosowanie remifentanylu skutkuje większą stabilnością hemodynamiczną pacjenta w porównaniu ze znieczuleniem z użyciem blokady splotu barkowego, natomiast użycie blokady wpływa na lepszą analgezję pooperacyjną w stosunku do pierwszej metody.

\section{Introduction}

Orthopaedic surgeries concerning upper limbs are nowadays very commonly performed medical procedures. However, being considerably invasive procedures, they require the presence of an anaesthetist. The modern era of shoulder affliction treatment was commenced by Codman in the 1930s. Shoulder joint arthroscopy was a rarely performed procedure until the 1980s. Today more than 1.4 million shoulder joint arthroscopies are performed annually [1]. This minimally invasive surgery is used to perform surgical procedures such as reconstruction of the rotator cuff, superior labrum anterior-posterior (SLAP) damages, long head of biceps tendinitis, glenoid labrum treatment, frozen shoulder (adhesive capsulitis) surgeries, or suprascapular nerve block [2]. There are several available methods of performing anaesthesia in patients undergoing shoulder joint arthroscopy. Each of them has to take into account, as well as the comfort of the patient, the reduction of bleeding in the operating field. Intraoperative hypotension can be obtained via two approaches: intravenous medications and peripheral nerve block. Attenuating pain during and after the procedure is a significant issue, which requires the application of an appropriate method of treatment [3-8]. Performing an interscalene muscle block of the brachial plexus is a method of regional anaesthesia applied by choice for procedures of the shoulder joint $[9,10]$. A relevant advantage of this method, other than hypotension, is prolonged analgesia - up to $18 \mathrm{~h}[8,11-14]$. Unfortunately, even with properly blocked nerves, the necessity to change to general anaesthesia reaches 8.7-13\% [3], or even 20\% [15], which in the case of positioning a patient on his/ her side or in a beach chair position is critically constricted. Therefore, as a rule, taking patients' comfort and safety into consideration, after peripheral nerve block, general anaesthesia is conducted. The method of choice, which is peripheral nerve block, has its limitations. Among them the most common are: primary damage of brachial plexus - a risk of deterioration of the condition and chronic obstructive pulmonary disease (COPD), a risk of phrenic nerve palsy, and lack of consent to perform the block $[11,12,16]$.

In the instance, when only general anaesthesia is performed, medications usually applied to obtain controlled hypotension are sodium nitroferricyanide, nitroglycerin, urapidil, labetalol, esmolol, and adenos- ine [11]. Another alternative is remifentanil, which, due to its pharmacokinetic properties, such as quick start and short duration of action, is especially advisable for patients with chronic respiratory distress $[17,18]$. Post-operative pain treatment, in this case, must be executed by the use of intravenous analgesic. Obtaining controlled hypotension, inevitable to perform shoulder arthroscopy procedure is related to a number of risks. Currently, there is no agreement regarding the definition of the marginal level to which systemic blood pressure can be lowered safely without the risk of tissue ischaemia. Eckenhoff defined controlled under-pressure as pharmacologically lowering mean arterial pressure (MAP) to 50-60 $\mathrm{mm} \mathrm{Hg}$. The pharmacological effect is often amplified by positioning a patient (beach chair position) and lifting the operated body part above the level of the heart $[11,16,18,19]$.

\section{Aim of the research}

The main objective of the thesis is to assess haemodynamic stability in patients undergoing arthroscopic shoulder joint surgery in two different types of anaesthesia: complex general anaesthesia and complex general and regional anaesthesia. The additional objective was the assessment of postoperative analgesia on the post-operative day (day 0) after surgery.

\section{Material and methods}

The research included 20 patients of both sexes, aged 18 to 69 years, classified pre-operatively as category I and II of physical status classification according to American Society of Anaesthesiologists (ASA), qualified to planned shoulder joint surgery performed with arthroscopy method. Exclusion criteria comprised: lack of consent to anaesthesia, neurological disorders, psychological disorders, addiction to alcohol or abusive substances, obesity (body mass index - BMI $>30.0 \mathrm{~kg} / \mathrm{m}^{2}$ ), haemorrhagic shock during the procedure, and allergic reaction to medicine administered during the anaesthesia. Pilot research was conducted in 2018-2019 in St. Rafal's Provincial Specialist Hospital in Czerwona Gora. Thirty minutes before the planned procedure every patient was given oral premedication consisting of $1 \mathrm{~g}$ paracetamol (Paracetamol 500 mg Laboratoria Polfa, Lodz, Poland) and $75 \mathrm{mg}$ pregabalin (Linefor $75 \mathrm{mg}$ Polpharma, Poland). After the arrival at the operating theatre, 
standard monitoring of vital signs was implemented: EKG, pulse oximetry, and noninvasive arterial pressure measurement. Distal vein cannulation and radial artery cannulation were performed under the control of ultrasound. Prior to the procedure patients were randomly divided into two groups: $\mathrm{A}$ and $\mathrm{B}$.

Patients from group A were subjected to general complex anaesthesia with tracheal intubation with the use of atropine (Atropinom Sulfuricum WZF $0.5 \mathrm{mg} / \mathrm{ml}$, Polfa Warsaw, Poland), remifentanil (Ultiva $2 \mathrm{mg}$ Aspen, Ireland), propofol (Propofol 1\% MCT/ LCT Fresenius, Germany), rocuronium (Roqurum $10 \mathrm{mg} / \mathrm{ml}$, Pharma Swiss, Czech Republic), oxygen, air, and sevoflurane (Sojourn 100\% Primal Healthcare, United Kingdom ).

Prior to the induction of anaesthesia, patients were preoxygenated with $100 \%$ oxygen through a face mask, and intravenous infusion of balanced multielectrolyte fluid was implemented (Optilyte $500 \mathrm{ml}$ Fresenius Kabi, Poland). The induction of anaesthesia was administered with a starting dose of $0.05 \mu \mathrm{g} /$ $\mathrm{kg} / \mathrm{min}$ of remifentanil infusion, additionally implementing a bolus of propofol $1.5-2.5 \mathrm{mg} / \mathrm{kg}$ total body weight (TBW). After obtaining unconsciousness, patients were ventilated with $100 \%$ oxygen.

Neuromuscular anaesthesia was provided by the administration of rocuronium $0.6 \mathrm{mg} / \mathrm{kg}$ TBW. Following tracheal intubation, the conduction anaesthesia was obtained by the supply of inhaled sevoflurane, in order for the minimum alveolar concentration (MAC) to amount to 1.0. In the event of a heart rate under 50 beats per minute, atropine was supplied in a dose of $500 \mu \mathrm{g}$. The infusion of remifentanil was performed with a syringe infusion pump (Perfusor Space B Braun, Germany). Remifentanil was titrated in doses from $0.05 \mu \mathrm{g} / \mathrm{kg} / \mathrm{min}$ to $2.0 \mu \mathrm{g} / \mathrm{kg} / \mathrm{min}$. The aim was to maintain MAP at 55-65 mm Hg. If MAP decreased to $50 \mathrm{~mm} \mathrm{Hg}$, the implementation of $5 \mathrm{mg}$ ephedrine (Ephedrinum hydrochloricum $25 \mathrm{mg} / \mathrm{ml}$ WZF Polfa Warszawa, Poland) was planned. Ten minutes before the end of the procedure every patient was supplied with $5 \mathrm{mg}$ of morphine (Morphine $10 \mathrm{mg} / \mathrm{ml}$, Kalceks, Latvia) prior to the termination of the infusion of remifentanil.

In group B patients interscalene muscle block of the brachial plexus using an out of plane technique was performed with the usage of $10 \mathrm{ml}$ of $0.5 \%$ ropivacaine (Ropimol $5 \mathrm{mg} / \mathrm{ml}$, Molteni, Italy) under the supervision of ultrasound and distal nerve stimulant with the following general complex anaesthesia with tracheal intubation with the use of: atropine, fentanyl (Fentanyl WZF $50 \mu \mathrm{g} / \mathrm{ml}$, Polfa Warszawa, Poland) propofol, rocuronium, oxygen, air, and sevoflurane. Prior to the induction of anaesthesia, patients were preoxygenated with 100\% oxygen through a face mask, and intravenous infusion of balanced multielectrolyte fluid was implemented. The induction of anaesthesia was administered with a starting dose of
$100 \mu \mathrm{g}$ fentanyl, subsequently implementing a bolus of propofol (1.5-2.5 mg/kg TBW). After obtaining unconsciousness, patients were ventilated with $100 \%$ oxygen through a face mask. Neuromuscular anaesthesia was provided by the administration of rocuronium - $0.6 \mathrm{mg} / \mathrm{kg}$ TBW. Following tracheal intubation, the conduction anaesthesia was obtained by the supply of sevoflurane, in order for the MAC to amount to 1.0. In the event of a heart rate below $50 \mathrm{bpm}$, atropine was supplied in a dose of $500 \mu \mathrm{g}$. If the MAP decreased to $50 \mathrm{~mm} \mathrm{Hg}$, the implementation of $5 \mathrm{mg}$ of ephedrine was planned.

During the procedure, in both groups, the parameters of haemodynamic condition were monitored every $10 \mathrm{~min}$ : heart rate (HR), mean arterial pressure (MAP), and oxygen saturation measured by pulse oximetry $\left(\mathrm{SpO}_{2}\right)$. Additionally, gas exchange parameters were assessed through arterial blood gas analysis. Oxygen saturation was assessed by defining the lactate level in the serum. The samples (blood) to both tests were drawn from the radial artery immediately before the input and after the termination of anaesthesia. Haemodynamic levels were registered with a vital signs monitor (BSM-3562, Nihon Khoden, Japan). General anaesthesia was performed with an anaesthetic device (Flow-i, Mauqet, Sweden). Brachial plexus block was conducted with an ultrasound device (Ezono 4000, Germany). Nerve stimulator (MultiStim, Pajunk, Germany), and regional anaesthesia needles (echplex+, Vaygon, France) were used to identify the plexus.

The assessment of post-surgical analgesia was held in the post-operative room of the operating theatre, and after sending patients to the Orthopaedic Unit of St. Rafal's Provincial Specialist Hospital in Czerwona Gora the following parameters were recorded: the intensity of the post-operative pain with VAS scale (visual analogue scale) immediately after sending them to the post-operative room and then every $4 \mathrm{~h}$. In post-operative analgesia ketoprofen (Ketonal $50 \mathrm{mg} / \mathrm{ml}$, Sandor, Austria) and metamizole (Metamizole $500 \mathrm{mg} / \mathrm{ml}$, Kalceks, Latvia) were provided intravenously in doses enabling effective alleviation of post-operative pain, which was established at VAS 1-3. In the case of unsatisfactory pain management (VAS scale $>3$ ) morphine intravenously was provided. Additionally, a total requirement of pain medication was assessed on the post-operative day (day 0). Consent to conduct the research was granted by the Bioethics Committee of Świętokrzyska Medical Chamber in Kielce (Komisja Bioetyki Świętokrzyskiej Izby Lekarskiej w Kielcach) (no. 63/2018).

\section{Statistical analysis}

The results elicited were stored in one database elaborated statistically. Several statistical techniques were used to evaluate the variables, e.g. arithme- 
tic mean, standard deviation (SD), and median. The $U$ Mann-Whitney test was used in two groups to compare haemodynamic parameters such as heart rate, mean arterial pressure, and oxygen saturation measured by pulse oximetry. In respective time criteria, Spearman rank correlation was applied to analyse haemodynamic parameters. T-test for dependable samples was used to determine the correlation between gas exchange parameters. The results were recorded in Statistica 13 software. The statistical salience was established at the level $p<0.05$.

\section{Results}

Spearman rank correlation demonstrated a significant dependence between heart rate parameters (HR) after $30 \mathrm{~min}$ in regard to HR parameters in each time interval in group A. Additionally, a positive correlation was declared in the majority between, for example, HR after $20 \mathrm{~min}$ and HR after $10 \min (r=0.6590, p=0.038)$, HR after $40 \min (r=0.7759, p=0.008)$, and HR after $50 \min (r=0.6623, p=0.037)$. Consecutively, HR after $40 \mathrm{~min}$ and HR after $50 \mathrm{~min}(r=0.9504, p<0.001)$, HR after $60 \min (r=0.8580, p=0.001)$, and HR after $70 \min (r=0.8289, p=0.003)$. Subsequently, the correlation was displayed between $\mathrm{HR}$ after $50 \mathrm{~min}$ and $\mathrm{HR}$ after $60 \min (r=0.8802, p=0.001)$ as well as HR after $70 \min (r=0.8562, p=0.002)$, and between HR after $60 \mathrm{~min}$ and HR after $70 \min (r=0.7922, p=0.006)$.

In group B fewer dependencies were manifested between HR parameters in comparison to group A.
The correlation was identified between $\mathrm{HR}$ after $30 \mathrm{~min}$ and HR after $10 \mathrm{~min}(r=0.6372, p=0.048)$, HR after $20 \min (r=0.8832, p=0.001)$, and HR after $40 \min (r=0.7205, p=0.019)$. Additionally, the dependence occurred between HR after 20 min and HR after $10 \min (r=0.8159, p=0.004)$, HR after $40 \mathrm{~min}$ and HR after 50 min $(r=0.9478, p<0.001)$, HR after $60 \mathrm{~min}$ $(r=0.7869, p=0.007)$, as well as between HR after $50 \mathrm{~min}$ and HR after $60 \mathrm{~min}(r=0.8377, p=0.002)$. The $U$ Mann-Whitney test demonstrated a statistically significant distinction between HR parameters after 30 min and the type of anaesthesia applied $(p=0.009)$ (Table 1).

After the analysis of the MAP in group A the Spearman rank correlation shown a relevant relationship between MAP parameters after 10 min and MAP after $30 \min (r=0.7978, p=0.006)$, and MAP after $70 \min (r=0.7193, p=0.019)$. Consecutively, between MAP after $50 \mathrm{~min}$ and MAP after $20 \mathrm{~min}(r=-0.9652$, $p<0.001)$, MAP after $40 \min (r=0.6412, p=0.046)$, as well as between MAP after 70 min and MAP after $30 \min (r=0.6775, p=0.031)$, and MAP after $60 \mathrm{~min}$ $(r=0.7204, p=0.019)$.

In group B fewer dependencies between MAP parameters were proven in comparison to group A. The correlation was displayed between MAP after $40 \mathrm{~min}$ and MAP after $50 \mathrm{~min}(r=0.7425, p=0.014)$. The $U$ Mann-Whitney test showed a statistically relevant distinction between MAP parameters after $60 \mathrm{~min}$ and the type of anaesthesia applied ( $p=0.035)$ (Table 2 ).

Table 1. Descriptive statistics of haemodynamic stability parameter HR in respective time intervals according to the anaesthesia used

\begin{tabular}{|c|c|c|c|c|c|c|c|c|c|}
\hline \multirow[t]{2}{*}{ Parameter } & & \multicolumn{8}{|c|}{ Descriptive statistics of analysed parameters } \\
\hline & & Mean & $\begin{array}{l}\text { Standard } \\
\text { deviation }\end{array}$ & Minimum & $\begin{array}{l}\text { Lower } \\
\text { quartile }\end{array}$ & Median & $\begin{array}{l}\text { Upper } \\
\text { quartile }\end{array}$ & Maximum & $\begin{array}{c}U \text { Mann-Whitney } \\
\text { test }\end{array}$ \\
\hline \multirow{2}{*}{$\begin{array}{l}\text { HR after } \\
10 \text { min }\end{array}$} & A & 70.40 & 6.22 & 59 & 65 & 71 & 76 & 79 & \multirow[t]{2}{*}{$p=0.218$} \\
\hline & B & 75.80 & 9.13 & 63 & 69 & 75.50 & 85 & 88 & \\
\hline \multirow{2}{*}{$\begin{array}{l}\text { HR after } \\
20 \text { min }\end{array}$} & A & 68.80 & 6.58 & 59 & 61 & 70 & 72 & 80 & \multirow[t]{2}{*}{$p=0.165$} \\
\hline & B & 74.90 & 10.98 & 54 & 70 & 74.50 & 83 & 91 & \\
\hline \multirow{2}{*}{$\begin{array}{l}\text { HR after } \\
30 \text { min }\end{array}$} & A & 68.60 & 6.11 & 62 & 63 & 68 & 73 & 79 & \multirow[t]{2}{*}{$p=0.009$} \\
\hline & B & 78.80 & 9.85 & 57 & 76 & 81.50 & 85 & 88 & \\
\hline \multirow{2}{*}{$\begin{array}{l}\text { HR after } \\
40 \text { min }\end{array}$} & A & 73.00 & 9.14 & 62 & 65 & 73 & 77 & 90 & \multirow[t]{2}{*}{$p=0.217$} \\
\hline & B & 79.20 & 11.84 & 59 & 69 & 81 & 87 & 100 & \\
\hline \multirow{2}{*}{$\begin{array}{l}\text { HR after } \\
50 \text { min }\end{array}$} & A & 74.80 & 8.99 & 61 & 69 & 74 & 78 & 94 & \multirow[t]{2}{*}{$p=0.353$} \\
\hline & $B$ & 81.50 & 13.75 & 65 & 70 & 79.50 & 91 & 110 & \\
\hline \multirow{2}{*}{$\begin{array}{l}\text { HR after } \\
60 \text { min }\end{array}$} & A & 74.90 & 10.68 & 62 & 65 & 76 & 77 & 97 & \multirow[t]{2}{*}{$p=0.123$} \\
\hline & B & 80.70 & 10.48 & 66 & 72 & 80.50 & 87 & 99 & \\
\hline \multirow{2}{*}{$\begin{array}{l}\text { HR after } \\
70 \text { min }\end{array}$} & A & 75.20 & 11.32 & 65 & 68 & 73.50 & 76 & 104 & \multirow[t]{2}{*}{$p=0.089$} \\
\hline & B & 80.10 & 8.84 & 65 & 76 & 79 & 85 & 99 & \\
\hline
\end{tabular}

$A$ - anaesthesia with the use of remifentanil, $B$ - general anaesthesia with brachial plexus block. 
Table 2. Descriptive statistics of haemodynamic stability parameter MAP in respective time intervals according to the anaesthesia used

\begin{tabular}{|c|c|c|c|c|c|c|c|c|c|}
\hline \multirow[t]{2}{*}{ Parameter } & & \multicolumn{8}{|c|}{ Descriptive statistics of analysed parameters } \\
\hline & & Mean & $\begin{array}{l}\text { Standard } \\
\text { deviation }\end{array}$ & Minimum & $\begin{array}{l}\text { Lower } \\
\text { quartile }\end{array}$ & Median & $\begin{array}{l}\text { Upper } \\
\text { quartile }\end{array}$ & Maximum & $\begin{array}{c}\text { U Mann-Whitney } \\
\text { test }\end{array}$ \\
\hline \multirow{2}{*}{$\begin{array}{l}\text { MAP after } \\
10 \mathrm{~min}\end{array}$} & A & 71.60 & 11.27 & 52 & 62 & 74 & 81 & 88 & \multirow[t]{2}{*}{$p=0.912$} \\
\hline & B & 71.50 & 10.15 & 47 & 69 & 72.50 & 78 & 84 & \\
\hline \multirow{2}{*}{$\begin{array}{l}\text { MAP after } \\
20 \text { min }\end{array}$} & A & 70.50 & 6.45 & 57 & 68 & 71 & 76 & 78 & \multirow[t]{2}{*}{$p=0.063$} \\
\hline & B & 65.10 & 7.06 & 52 & 60 & 68.50 & 70 & 70 & \\
\hline \multirow{2}{*}{$\begin{array}{l}\text { MAP after } \\
30 \mathrm{~min}\end{array}$} & A & 66.00 & 7.32 & 54 & 62 & 64 & 72 & 78 & \multirow[t]{2}{*}{$p=0.247$} \\
\hline & $B$ & 70.40 & 8.91 & 55 & 65 & 71 & 75 & 86 & \\
\hline \multirow{2}{*}{$\begin{array}{l}\text { MAP after } \\
40 \text { min }\end{array}$} & A & 68.20 & 7.33 & 56 & 63 & 68.50 & 75 & 77 & \multirow[t]{2}{*}{$p=0.393$} \\
\hline & B & 65.20 & 7.25 & 53 & 62 & 64.50 & 69 & 78 & \\
\hline \multirow{2}{*}{$\begin{array}{l}\text { MAP after } \\
50 \text { min }\end{array}$} & $A$ & 69.70 & 6.25 & 62 & 65 & 68 & 73 & 81 & \multirow[t]{2}{*}{$p=0.165$} \\
\hline & $B$ & 64.60 & 9.16 & 52 & 57 & 64 & 71 & 79 & \\
\hline \multirow{2}{*}{$\begin{array}{l}\text { MAP after } \\
60 \text { min }\end{array}$} & A & 69.00 & 5.44 & 60 & 64 & 70 & 73 & 78 & \multirow[t]{2}{*}{$p=0.035$} \\
\hline & B & 63.10 & 6.28 & 49 & 62 & 63.50 & 66 & 72 & \\
\hline \multirow{2}{*}{$\begin{array}{l}\text { MAP after } \\
70 \text { min }\end{array}$} & A & 70.00 & 5.33 & 60 & 65 & 71 & 73 & 79 & \multirow[t]{2}{*}{$p=0.684$} \\
\hline & B & 69.80 & 11.55 & 49 & 65 & 69 & 80 & 90 & \\
\hline
\end{tabular}

$A$ - anaesthesia with the use of remifentanil, $B$-general anaesthesia with brachial plexus block.

Analysing the parameter of saturation with general anaesthesia with remifentanil applied Spearman rank correlation demonstrated significant dependency between $\mathrm{SpO}_{2}$ parameters after 60 min and $\mathrm{SpO}_{2}$ after $10 \min (r=0.7294, p=0.017), \mathrm{SpO}_{2}$ after $20 \mathrm{~min}$ $(r=0.6508, p=0.042), \mathrm{SpO}_{2}$ after $30 \mathrm{~min}(r=0.7043$, $p=0.023)$, and $\mathrm{SpO}_{2}$ after $50 \mathrm{~min}(r=0.7454, p=0.013)$. Consecutively, between $\mathrm{SpO}_{2}$ parameters after $70 \mathrm{~min}$ and $\mathrm{SpO}_{2}$ after $30 \min (r=0.7906, p=0.006), \mathrm{SpO}_{2}$ after $40 \mathrm{~min}(r=0.6642, p=0.036), \mathrm{SpO}_{2}$ after $50 \mathrm{~min}$ $(r=0.7968, p=0.006)$, and $\mathrm{SpO}_{2}$ after $60 \mathrm{~min}$ $(r=0.8018, p=0.005)$. Additionally, the relationship occurred between $\mathrm{SpO}_{2}$ parameters after $30 \mathrm{~min}$ and $\mathrm{SpO}_{2}$ after $40 \mathrm{~min}(r=0.8402, p=0.002)$ as well as between $\mathrm{SpO}_{2}$ parameters after $40 \mathrm{~min}$ and $\mathrm{SpO}_{2}$ after $50 \min (r=0.6880, p=0.028)$. $U$ Mann-Whitney test did not prove any relevant correlation between the two groups.

In the case of general anaesthesia with brachial plexus block, fewer dependencies were noted between $\mathrm{SpO}_{2}$ parameters in reference to general anaesthesia with remifentanil. The relationship between $\mathrm{SpO}_{2}$ parameters after $40 \mathrm{~min}$ and $\mathrm{SpO}_{2}$ after $30 \mathrm{~min}$ $(r=0.7516, p=0.012), \mathrm{SpO}_{2}$ after $50 \mathrm{~min}(r=0.8810$, $p=0.001)$, and $\mathrm{SpO}_{2}$ after $70 \mathrm{~min}(r=0.7327, p=0.016)$. Additionally, the correlation occurred between $\mathrm{SpO}_{2}$ after $50 \mathrm{~min}$ and $\mathrm{SpO}_{2}$ after $70 \mathrm{~min}(r=0.9031, p<0.001)$ (Table 3).

The average $\mathrm{pH}$ value before and after the implementation of general anaesthesia with remifentanil presented similar values, which is indicated by values of standard deviation (before \pm 0.01 , after \pm 0.04 ). $T$-test for dependent samples displayed relevant correlation for the $\mathrm{pH}(p=0.001)$ parameter in group A (Table 4). T-test for dependent samples did not present any relevant dependency for the lactate levels before and after applied anaesthesia in the group mentioned.

$T$-test for dependent samples presented relevant correlation for gas exchange parameters $\mathrm{pH} p=0.005$ in group B (Table 5). Greater discrepancies of the average value of standard deviation were noted in comparison to the same parameters of gas exchange in the group in which general anaesthesia with remifentanil was performed.

The $U$ Mann-Whitney test did not prove any relevant correlation between the pain medications administered following the surgery and the type of anaesthesia. Patients after general anaesthesia with remifentanil required the provision of higher doses of morphine in pain treatment. In the case of the medication mentioned, the statistical salience amounted to $p=0.052$ (Table 6 ). Analysing the VAS scale and the type of anaesthesia, pain scores in group A patients reached maximally 6.40 points. In group B the above value amounted to 3.75 points. The salience value totalled $p=0.052$ (Table 7).

\section{Discussion}

The usage of controlled hypotension in conjunction with positioning a patient in a 'beach chair' posi- 
Table 3. Descriptive statistics of haemodynamic stability parameter $\mathrm{SpO}_{2}$ in respective time intervals according to the anaesthesia used

\begin{tabular}{|c|c|c|c|c|c|c|c|c|c|}
\hline \multirow[t]{2}{*}{ Parameter } & & \multicolumn{8}{|c|}{ Descriptive statistics of analysed parameters } \\
\hline & & Mean & $\begin{array}{l}\text { Standard } \\
\text { deviation }\end{array}$ & Minimum & $\begin{array}{l}\text { Lower } \\
\text { quartile }\end{array}$ & Median & $\begin{array}{l}\text { Upper } \\
\text { quartile }\end{array}$ & Maximum & $\begin{array}{c}\text { U Mann-Whitney } \\
\text { test }\end{array}$ \\
\hline \multirow{2}{*}{$\begin{array}{l}\mathrm{SpO}_{2} \text { after } \\
10 \mathrm{~min}^{-}\end{array}$} & A & 97.80 & 1.14 & 96 & 97 & 98 & 99 & 99 & \multirow[t]{2}{*}{$p=0.853$} \\
\hline & $\mathrm{B}$ & 97.80 & 1.62 & 95 & 96 & 98 & 99 & 100 & \\
\hline \multirow{2}{*}{$\begin{array}{l}\mathrm{SpO}_{2} \text { after } \\
20 \mathrm{~min}\end{array}$} & A & 97.80 & 0.92 & 97 & 97 & 97.50 & 99 & 99 & \multirow[t]{2}{*}{$p=0.631$} \\
\hline & $\mathrm{B}$ & 98 & 0.82 & 97 & 97 & 98 & 99 & 99 & \\
\hline \multirow{2}{*}{$\begin{array}{l}\mathrm{SpO}_{2} \text { after } \\
30 \text { min }\end{array}$} & A & 98 & 0.82 & 97 & 97 & 98 & 99 & 99 & \multirow[t]{2}{*}{$p=0.529$} \\
\hline & B & 97.70 & 0.95 & 96 & 97 & 98 & 98 & 99 & \\
\hline \multirow{2}{*}{$\begin{array}{l}\mathrm{SpO}_{2} \text { after } \\
40 \text { min }\end{array}$} & A & 97.50 & 0.97 & 96 & 97 & 98 & 98 & 99 & \multirow[t]{2}{*}{$p=0.684$} \\
\hline & B & 97.40 & 0.97 & 96 & 97 & 97 & 98 & 99 & \\
\hline \multirow{2}{*}{$\begin{array}{l}\mathrm{SpO}_{2} \text { after } \\
50 \mathrm{~min}\end{array}$} & A & 97.50 & 1.08 & 96 & 96 & 98 & 98 & 99 & \multirow[t]{2}{*}{$p=0.684$} \\
\hline & $\mathrm{B}$ & 97.40 & 0.97 & 96 & 97 & 97 & 98 & 99 & \\
\hline \multirow{2}{*}{$\begin{array}{l}\mathrm{SpO}_{2} \text { after } \\
60 \text { min }\end{array}$} & A & 97.60 & 0.97 & 96 & 97 & 98 & 98 & 99 & \multirow[t]{2}{*}{$p=0.267$} \\
\hline & B & 97.10 & 1.20 & 96 & 96 & 97 & 98 & 99 & \\
\hline \multirow{2}{*}{$\begin{array}{l}\mathrm{SpO}_{2} \text { after } \\
70 \text { min }\end{array}$} & A & 97.80 & 1.03 & 96 & 97 & 98 & 99 & 99 & \multirow[t]{2}{*}{$p=0.631$} \\
\hline & B & 97.60 & 1.35 & 96 & 97 & 97 & 99 & 100 & \\
\hline
\end{tabular}

$A$ - anaesthesia with the use of remifentanil, $B$ - general anaesthesia with brachial plexus block.

Table 4. Descriptive statistics of gas exchange parameters before and after the application of general anaesthesia with the use of remifentanil - group A

\begin{tabular}{|c|c|c|c|c|c|c|c|c|c|}
\hline \multirow[t]{2}{*}{ Parameter } & \multicolumn{9}{|c|}{ Descriptive statistics of analysed parameters } \\
\hline & & Mean & $\begin{array}{l}\text { Standard } \\
\text { deviation }\end{array}$ & Minimum & $\begin{array}{l}\text { Lower } \\
\text { quartile }\end{array}$ & Median & $\begin{array}{l}\text { Upper } \\
\text { quartile }\end{array}$ & Maximum & $T$-test \\
\hline \multirow[t]{2}{*}{ Lactates } & Before & 10.52 & 3.89 & 5.70 & 7.00 & 10.35 & 16.80 & 16.80 & \multirow[t]{2}{*}{$p=0.524$} \\
\hline & After & 11.50 & 5.28 & 5.30 & 9.50 & 10.50 & 24.00 & 24.00 & \\
\hline \multirow[t]{2}{*}{$\mathrm{pH}$} & Before & 7.40 & 0.01 & 7.39 & 7.40 & 7.41 & 7.43 & 7.430 & \multirow[t]{2}{*}{$p=0.001$} \\
\hline & After & 7.31 & 0.04 & 7.26 & 7.28 & 7.31 & 7.36 & 7.360 & \\
\hline
\end{tabular}

Table 5. Descriptive statistics of gas exchange parameters before and after the application of general anaesthesia and brachial plexus block - group B

\begin{tabular}{|c|c|c|c|c|c|c|c|c|c|}
\hline \multirow[t]{2}{*}{ Paramete } & & \multicolumn{8}{|c|}{ Descriptive statistics of analysed parameters } \\
\hline & & Mean & $\begin{array}{l}\text { Standard } \\
\text { deviation }\end{array}$ & Minimum & $\begin{array}{l}\text { Lower } \\
\text { quartile }\end{array}$ & Median & $\begin{array}{l}\text { Upper } \\
\text { quartile }\end{array}$ & Maximum & $T$ test \\
\hline \multirow[t]{2}{*}{ Lactates } & Before & 9.84 & 3.23 & 5.80 & 7.30 & 9.10 & 12.50 & 16.00 & $p=0.190$ \\
\hline & After & 19.33 & 22.26 & 6.30 & 7.70 & 13.70 & 17.40 & 81.30 & \\
\hline \multirow[t]{2}{*}{$\mathrm{pH}$} & Before & 7.41 & 0.95 & 7.40 & 7.39 & 7.42 & 7.43 & 7.43 & $p=0.005$ \\
\hline & After & 7.33 & 0.035 & 7.29 & 7.31 & 7.33 & 7.35 & 7.41 & \\
\hline
\end{tabular}

tion is the most popular method to suppress inter-operative bleeding. Thereby this approach ensures better visualisation of the operating field, reduces blood loss, and shortens the length of the procedure $[18,20]$.

In the research haemodynamic parameters such as MAP, HR, and $\mathrm{SpO}_{2}$ were subjected to analysis. The heart rate measured in every time interval in patients after general anaesthesia with brachial plexus block (group B) was higher in comparison to the heart rate in patients who were subjected to anaesthesia with remifentanil (group A). The HR parameter between the two groups differed substantially after $30 \mathrm{~min}$ 
Table 6. Descriptive statistics of the pain medications applied, according to the anaesthesia used

\begin{tabular}{|c|c|c|c|c|c|c|c|c|c|}
\hline \multirow[t]{2}{*}{ Parameter } & & \multicolumn{8}{|c|}{ Descriptive statistics of analysed parameters } \\
\hline & & Mean & $\begin{array}{l}\text { Standard } \\
\text { deviation }\end{array}$ & Minimum & $\begin{array}{l}\text { Lower } \\
\text { quartile }\end{array}$ & Median & $\begin{array}{l}\text { Upper } \\
\text { quartile }\end{array}$ & Maximum & $\begin{array}{c}U \text { Mann-Whitney } \\
\text { test }\end{array}$ \\
\hline \multirow{2}{*}{$\begin{array}{l}\text { Metamizole } \\
{[\mathrm{mg}]}\end{array}$} & A & 1650 & 1001.39 & 0 & 1000 & 1500 & 2500 & 3000 & \multirow[t]{2}{*}{$p=0.436$} \\
\hline & B & 2000 & 1054.09 & 0 & 1000 & 2000 & 3000 & 3000 & \\
\hline \multirow{2}{*}{$\begin{array}{l}\text { Ketoprofen } \\
{[\mathrm{mg}]}\end{array}$} & A & 130 & 67.50 & 0 & 100 & 100 & 200 & 200 & \multirow[t]{2}{*}{$p=0.739$} \\
\hline & B & 120 & 63.25 & 0 & 100 & 100 & 200 & 200 & \\
\hline \multirow{2}{*}{$\begin{array}{l}\text { Morphine } \\
\text { [mg] }\end{array}$} & A & 12 & 7.53 & 0 & 5 & 15 & 20 & 20 & \multirow[t]{2}{*}{$p=0.052$} \\
\hline & $B$ & 5.50 & 5.50 & 0 & 0 & 5 & 10 & 15 & \\
\hline
\end{tabular}

$A$ - anaesthesia with the use of remifentanil, $B$ - general anaesthesia with brachial plexus block.

Table 7. Descriptive statistics of the VAS scale of pain according to the anaesthesia used

\begin{tabular}{|c|c|c|c|c|c|c|c|c|c|}
\hline \multirow[t]{2}{*}{ Parameter } & & \multicolumn{8}{|c|}{ Descriptive statistics of analysed parameters } \\
\hline & & Mean & $\begin{array}{l}\text { Standard } \\
\text { deviation }\end{array}$ & Minimum & $\begin{array}{l}\text { Lower } \\
\text { quartile }\end{array}$ & Median & $\begin{array}{l}\text { Upper } \\
\text { quartile }\end{array}$ & Maximum & $\begin{array}{c}\text { U Mann-Whitney } \\
\text { test }\end{array}$ \\
\hline \multirow[t]{2}{*}{ VAS scale } & A & 3.46 & 1.41 & 1.50 & 2.60 & 3.19 & 4.17 & 6.40 & \multirow[t]{2}{*}{$p=0.052$} \\
\hline & B & 2.30 & 0.82 & 1.33 & 1.60 & 2.19 & 2.67 & 3.75 & \\
\hline
\end{tabular}

$A$ - anaesthesia with the use of remifentanil, $B$-general anaesthesia with brachial plexus block.

of the surgery. $U$ Mann-Whitney test demonstrated salience $p=0.009$. In every examined case the heart rate was lower in group A than in group B. During the procedure, patients from group A had lower heart rate levels, which remained in a similar range. In the available literature concerning controlled hypotension the authors emphasise the importance of not only the lowered arterial pressure but also prevention of reflexive tachycardia as being the element that may lead to the increase of inter-operative bleeding and the deterioration of visibility of the operating field [18, 21].

The analysed parameter of mean arterial pressure had more similar values to one another in A group, which indicates higher haemodynamic stability. Moreover, MAP values in the majority of patients in group A were higher in comparison to group B patients. In the $60^{\text {th }}$ min of the surgery, the widest discrepancy in MAP values was recorded between the analysed groups. The statistical salience for this parameter amounted to $p=0.035$. In patients from group B, greater fluctuations of MAP values were noted, which suggests lower haemodynamic stability for this method of anaesthesia. Despite the popularity of controlled hypotension with the considerable lowering of MAP in procedures of shoulder arthroscopy, the risk of serious complications due to ischaemia of internal organs has to be taken into consideration. There are reports in the literature about neurological complications such as cerebral vascular accident, cerebral death, vision loss, internuclear paralysis (ophthalmoplegia), and other critical conditions regarding the central nervous system [18, 20-22]. Available literature does not point to unequivocally safe MAP values in controlled hypotension. The majority of authors advise maintaining MAP $>50 \mathrm{~mm} \mathrm{Hg}$ or MAP reduction by no more than $20 \%$ of the output value for each patient. In the population partaking in the study, lowering of MAP, which required pharmacological intervention resulting in the necessity of providing ephedrine, occurred in 3 patients from group B.

Arterial blood saturation in both groups had similar values. $U$ Mann-Whitney test did not present any relevant correlation between the examined groups.

The lactate level and the rate of acid-base balance were used as a standard of tissue perfusion (safe hypotension).

The analysis of the arterial blood $\mathrm{pH}$ values before and after applying general anaesthesia with remifentanil demonstrated similar values, which proves better stability of acid-base balance during anaesthesia. In the case of the mentioned parameter in group A a high statistical salience occurred: $p=0.001$. Analysing the arterial blood $\mathrm{pH}$ values in group $\mathrm{B}$ patients the $T$-test also showed the statistical salience $(p=0.005)$. The analysis of the lactate levels did not present relevant statistical values in any study group.

Another aspect under observation was the analysis of total demand for pain medications on the postoperative day (day 0). Comparing the application of pain medications in the two groups, a greater demand for morphine was displayed in group A almost by half. Post-operative pain measured by VAS scale was 
analogically more persistent in the group anaesthetised with remifentanil. The above result confirms the effectiveness of brachial plexus block in treating postoperative pain after a shoulder arthroscopy procedure and thereby the reduction of the provision of narcotic pain medications in the post-operative period [3]. The analysis of the intake of ketoprofen and metamizole did not present statistical salience.

\section{Conclusions}

If the necessity of implementing controlled hypotension for the surgical procedure occurs, the use of remifentanil results in higher haemodynamic stability than in the case of anaesthesia with brachial plexus block. Using brachial plexus block for shoulder arthroscopy results in better post-operative analgesia in comparison to anaesthesia with remifentanil.

\section{Acknowledgments}

The research was conducted within project no. WND-RPSW.02.01.00-26-005/13 'The purchase of scientific and testing equipment for the needs of St. Rafal's Provincial Specialist Hospital in Czerwona Góra.'

\section{Conflict of interest}

The authors declare no conflict of interest.

\section{References}

1. Bhaskar SB, Manjuladevi M. Shoulder arthroscopy and complications: can we afford to relax? Indian J Anaesth 2015; 59: 335-337.

2. Miller MD, Chhabra A, Safran M. Artroskopia. Elsevier Urban \& Partner, Wrocław 2012.

3. Sulaiman L, MacFarlane R, Waseem M. Current concept in ansesthesia for shoulder surgery. Open Orthop J 2013; 7: 323-328.

4. Soderlund A, Westman L, Ersmark H. Analgesia following arthroscopy a comparison of intra-articular morphine, pethidine and fentanyl. Acta Anaesthesiol Scand 1997; 41: 6-11.

5. Nagasaki G, Tanaka M, Saito A. Postoperative analgesia with morphine with or without diclofenac after shoulder surgery. Masui 2002; 51: 846-850.

6. Beecroft C, Coventry D. Anesthesia for shoulder surgery. Contin Educ Anaesth Crit Care Pain 2008; 8: 193-198.

7. Singelyn FJ, Lhotel L, Fabre B. Pain relief after arthroscopic shoulder surgery: a comparsion of intraarticular analgesia, suprascapular nerve block and intrascalene brachial plexus block. Anesth Analg 2004; 99: 589-592.

8. Misiołek H, Zajączkowska R, Daszkiewicz A, Woroń J, Dobrogowski J, Wordliczek J, Owczuk R. Postępowanie w bólu pooperacyjnym 2018 - stanowisko Sekcji Znieczulenia Regionalnego i Terapii Bólu Polskiego Towarzystwa Anestezjologii i Intensywnej Terapii, Polskiego Towarzystwa Znieczulenia Regionalnego i Leczenia Bólu, Polskiego Towarzystwa Badania Bólu oraz Konsultanta Krajowego w dziedzinie anestezjologii i intensywnej terapii. Anestezjol Intens Ter 2018; 3: 175-203.
9. Tran QH, Elgueta MF, Aliste J, Finlayson RJ. Diaphragm-sparing nerve blocks for shoulder surgery. Reg Anesth Pain Med 2017; 1: 32-38.

10. Aliste J, Bravo D, Layera S, et al. Randomized comparison between interscalene and costoclavicular blocks for arthroscopic shoulder burgery. Reg Anesth Pain Med 2019; 44: 472-477.

11. Larsen R. Anestezjologia. Edra Urban \& Partner, Wrocław 2013

12. Hadźić A, Vloka J. Blokady nerwów obwodowych - zasady i praktyka. Medipage, Warsaw 2008.

13. D'Alessio J, Rosenblum M, Shea K. A retrospective comparison of interscalene block and general anaesthesia for ambulatory surgery shoulder arthroscopy. Reg Anesth 1995; 20: 62-68

14. Borgeat A, Ekatodramis G. Anaesthesia for shoulder surgery. Best Pract ResClinAnaesthesiol 2002; 16: 211-225.

15. Zwolakiewicz L, Ostojowski R, Basiński A. Porównanie trzech metod leczenia po operacjach artroskopowych stawu ramiennego. Kliniczny efekt działania morfiny na receptory obwodowe. Anestezjol Intens Ter 2005; 2: 117-121.

16. Hewson DW, Oldman M, Bedforth NM. Regional anaesthesia for shoulder surger. BJA Education 2019; 19: 98-104.

17. Kim SH, So KY, Jeong YN. The hemodynamic changes during the infusion of remifentanil for patients under sevoflurane anesthesia during arthroscopic shoulder surgery. Korean J Anesthesiol 2009; 56: 497-501.

18. Sieśkiewicz A, Drozdowski A, Rogowski M. Ocena korelacji średniego ciśnienia tętniczego z krwawieniem śródoperacyjnym przy wolnej czynności serca w trakcie endoskopowej chirurgii zatok przynosowych. Otolaryngol Pol 2010; 64: 225-228.

19. Abraham A. Anaesthetic considerations for shoulder surgery. South Afr J Anaesth Analg 2018; 24: 54-57.

20. Gillespie R, Shishani Y, Streit J. The safety of controlled hypotension for shoulder arthroscopy in the beach-chair position. J Bone Joint Surg Am 2012; 94: 1284-1290.

21. Cantarella G, La Camera G, Di Marco P. Controlled hypotension during middle ear surgery: hemodynamic effects of remifentanil vs nitroglycerin. Ann Ital Chir 2018; 89: 283-286.

22. Lee JH, Min KT, Chun YM, Kim EJ, Choi SH. Effects of beach-chair position and induced hypotension on cerebral oxygen saturation In patients undergoing arthroscopic shoulder surgery. Arthroscopy 2011; 27: 889-894.

\section{Address for correspondence:}

\section{Paulina M. Jasek}

Department of Anaesthesiology and Intensive Care

St. Rafal's Provincial Specialist Hospital

Czerwona Gora, Poland

Phone: +48 661031503

E-mail: paulina_jasek_@vp.pl 